\title{
Carbon and nitrogen stocks in soils under different forms of use in the Cerrado
}

\author{
Adilson A. Costa ${ }^{1}$, Bruno de O. Dias ${ }^{1}$, Vânia da S. Fraga ${ }^{1}$, Charles C. Santana ${ }^{2}$ \& Núbia da Silva ${ }^{3}$ \\ ${ }^{1}$ Universidade Federal da Paraíba/Centro de Ciências Agrárias/Programa de Pós-Graduação em Ciência do Solo. Areia, PB, Brasil. E-mail: agroadalves@gmail.com \\ (Corresponding author) - ORCID: 0000-0002-6773-9219; brunodiascca@gmail.com - ORCID: 0000-0003-1259-5921; vfraga@cca.ufpb.br - ORCID: 0000-0003- \\ 0181-0753 \\ ${ }^{2}$ Universidade Federal de Viçosa/Centro de Ciências Agrárias/Programa de Pós-Graduação em Engenharia Agrícola. Viçosa, MG, Brasil. E-mail: \\ santana.agr@hotmail.com - ORCID: 0000-0002-3773-7415 \\ ${ }^{3}$ Universidade do Estado da Bahia/Departamento de Ciências Humanas. Barreiras, BA, Brasil. E-mail: nubiaetnobio@gmail.com - ORCID: 0000-0001-8558-8250
}

\begin{abstract}
The soil is an important component in the biogeochemical cycling of carbon (C) and nitrogen (N). The objective of this study was to evaluate the changes caused by different types of land use on the C and $\mathrm{N}$ stocks in areas of Cerrado at different depths: area under conventional tillage, no-tillage, grazing, eucalyptus and area under native vegetation of Cerrado in the municipality of Luis Eduardo Magalhães, BA, Brazil. The highest $\mathrm{C}$ content was found for no-tillage area in the surface layer up to $10 \mathrm{~cm}$; however, there was a decrease in its content along the depths. Areas under no-tillage had lower values of $\mathrm{C}$ in the surface layer $(0-5 \mathrm{~cm})$ and below $20 \mathrm{~cm}$. Among these, $\mathrm{C}$ stocks were significantly lower compared to the use of grass and eucalyptus at the depth of up to $40 \mathrm{~cm}$. Considering the depth of $0-60 \mathrm{~cm}$, the highest $\mathrm{C}$ stock was found in areas under native vegetation, $62.81 \mathrm{Mg} \mathrm{ha}^{-1}$, followed by the area under cultivation with eucalyptus, $60.70 \mathrm{Mg} \mathrm{ha}^{-1}$. The lowest $\mathrm{C}$ stocks were found in areas under conventional use, $44.87 \mathrm{Mg} \mathrm{ha}^{-1}$. Conventional planting reduced $\mathrm{N}$ stocks by up to 61 and $56 \%$ when compared to areas under native Cerrado vegetation and eucalyptus plantations, respectively, both at a depth of up to $10 \mathrm{~cm}$. Therefore, land use practices such as eucalyptus cultivation and no-tillage contribute to $\mathrm{C}$ and $\mathrm{N}$ storage over time.
\end{abstract}

Key words: soil organic matter, pasture, no-tillage

\section{Estoque de carbono e de nitrogênio em solos sob diferentes formas de uso no Cerrado}

RESUMO: O solo representa um importante componente no ciclo biogeoquímico do carbono (C) e do nitrogênio $(\mathrm{N})$. Objetivou-se, nesta pesquisa, avaliar as mudanças provocadas por diferentes formas de uso do solo sobre os estoques de carbono e nitrogênio em áreas de Cerrado em profundidade de até $60 \mathrm{~cm}$ : área sob plantio convencional, plantio direto, pastagem, eucalipto e área sob vegetação nativa de Cerrado na região de Luís Eduardo Magalhães, BA. O maior teor de $\mathrm{C}$ foi encontrado para área de plantio direto na camada superficial até $10 \mathrm{~cm}$; porém, houve decréscimo em seu teor ao longo das profundidades. Áreas sob plantio convencional apresentaram valores menores de estoque de $C$ na camada superficial $(0-5 \mathrm{~cm})$ e abaixo de $20 \mathrm{~cm}$. Entre estas, os estoques de $\mathrm{C}$ foram significativamente inferiores em comparação à utilização de pastagem e eucalipto na profundidade de até $40 \mathrm{~cm}$. Considerando a profundidade de 0-60 cm, o maior estoque de $\mathrm{C}$ foi encontrado nas áreas sob vegetação nativa, com $62,81 \mathrm{Mg} \mathrm{ha}^{-1}$, seguida pela área sob cultivo de eucalipto, com $60,70 \mathrm{Mg} \mathrm{ha}^{-1}$. Os menores estoques de $\mathrm{C}$ foram encontrados nas áreas sob uso convencional, com $44,87 \mathrm{Mg} \mathrm{ha}^{-1}$. O plantio convencional reduziu os estoques de $\mathrm{N}$ em até 61 e $56 \%$ em relação às áreas sob vegetação nativa de Cerrado e plantio de eucalipto, respectivamente, ambas na profundidade de até $10 \mathrm{~cm}$. Portanto, práticas de uso do solo como eucalipto e plantio direto contribuem para armazenar carbono e nitrogênio ao longo do tempo.

Palavras-chave: matéria orgânica do solo, pastagem, plantio direto 


\section{INTRODUCTION}

Changes in land use caused by anthropic action have the effect of altering the dynamics of soil organic matter (SOM) and, consequently, of carbon (C) and nitrogen (N) stocks, when native areas are converted to agricultural systems (Frazão et al., 2010). Associated with inadequate management practices, this effect causes degradation and reduction in agricultural yield (Guareschi et al., 2012; 2014; Costa et al., 2015).

In view of this scenario, the adoption of conservation measures for land management and use promotes greater soil conservation, and organic matter residues provide numerous benefits for the soil-plant system, being essential in low-C agriculture (Costa et al., 2015). However, there are still disagreements between results on the forms of land use that store more $\mathrm{C}$ and $\mathrm{N}$. Therefore, it is necessary to intensify studies that identify the best form of land use for the Cerrado, enabling the sustainability of the environment.

The planting of pasture causes reduction in soil C stocks (Dortzbach et al., 2015). However, Pereira et al. (2010) found that in no-tillage there was a $15 \%$ increase in total organic carbon compared to conventional planting at a depth of up to $25 \mathrm{~cm}$. Similar results were also found by Matias et al. (2009) in Cerrado areas. Research results have also shown that soils under eucalyptus plantations can increase $\mathrm{C}$ and $\mathrm{N}$ stocks when adequately managed (Tchienkoua \& Zeach, 2004).

Thus, the objective of this study was to evaluate the changes caused by five forms of land use on $\mathrm{C}$ and $\mathrm{N}$ stocks in Cerrado areas.

\section{Material ANd Methods}

The study was conducted in commercial plantations located in the municipality of Luís Eduardo Magalhães, extreme west of Bahia, Brazil, between the coordinates $11^{\circ} 51^{\prime} 8^{\prime \prime}$ and $12^{\circ} 33^{\prime} 50^{\prime \prime} \mathrm{S}$ and $45^{\circ} 37^{\prime} 50^{\prime \prime}$ and $46^{\circ} 23^{\prime} 35^{\prime \prime} \mathrm{W}$, with an altitude of $763 \mathrm{~m}$.

The average annual rainfall of the region is $1,000 \mathrm{~mm}$, with a hot and dry Aw climate, according to the Köppen-Geiger classification, with rainy season between October and March, with an average temperature from 22 to $30^{\circ} \mathrm{C}$.

The study areas have predominance of deep, well drained Oxisols, with flat relief and low contents of organic matter.

Five areas with different forms of use were studied:

- Area under conventional planting (ACP): Located at Busado Farm, altitude of $769 \mathrm{~m}$, whose coordinates are $12^{\circ} 54^{\prime} 815^{\prime \prime} \mathrm{S}$ and $45^{\circ} 29^{\prime} 873^{\prime \prime}$ W. Area under conventional system where fertilizations, liming and management were performed according to soil analysis and recommendations for the Cerrado. In the last three seasons, the following crops were cultivated: maize (years 2013/2014); soybean (years 2014/2015); cotton (years 2015/2016). Fertilization in the last season was $354 \mathrm{~kg} \mathrm{ha}^{-1}$ of urea, $204 \mathrm{~kg} \mathrm{ha}^{-1}$ of single superphosphate and $350 \mathrm{~kg} \mathrm{ha}^{-1}$ of potassium chloride.

- Area under pasture planting (APA): Located at Strassburges Farm, altitude of $786 \mathrm{~m}$, whose coordinates are $12^{\circ} 14^{\prime} 22^{\prime \prime} \mathrm{S}$ and $45^{\circ} 49^{\prime} 773^{\prime \prime}$ W. Area under pasture of palisade grass (Urochloa brizantha cv. Marandu), and the last crops were: beans (year $2013 / 2014$ ), pasture (year 2014/2015) and pasture (2015/2016).
Pasture fertilization consisted of $100 \mathrm{~kg}$ of urea, $350 \mathrm{~kg}$ of single superphosphate and $100 \mathrm{~kg}$ of potassium chloride. The pasture was sown in a row at spacing of $0.45 \mathrm{~m}$, with production of $14 \mathrm{t}$ of dry mass.

- Area under no-tillage (ANT): Located at Bela Vista Farm, altitude of $848 \mathrm{~m}$, and coordinates $12^{\circ} 1^{\prime} 333^{\prime \prime} \mathrm{S}$ and $46^{\circ} 9^{\prime} 332^{\prime \prime} \mathrm{W}$. Area under the form of use with no-tillage without soil turning, implemented since the agricultural year of 2010/2011, with cultivation of cotton (year 2013/2014), maize (year 2014/2015) and soybean (year 2015/2016). Fertilization and liming were performed according to recommendations for the Cerrado. Millet (Pennisetum glaucum) was used in the off-season for soil cover and straw supply on the soil surface.

- Area under eucalyptus plantation (AEU): Located at Palmeiras I Farm, altitude of $809 \mathrm{~m}$ and coordinates $12^{\circ} 21^{\prime} 446^{\prime \prime} \mathrm{S}$ and $45^{\circ} 56^{\prime} 212^{\prime \prime} \mathrm{W}$. Area under eucalyptus plantation since $2006 / 2007$, where soybean had been previously cultivated. Fertilization for eucalyptus consisted of $200 \mathrm{~kg}$ of urea, split into $100 \mathrm{~kg}$ in the first month and $100 \mathrm{~kg}$ in the third, and $200 \mathrm{~kg} \mathrm{ha}^{-1}$ of single superphosphate.

- Area under native Cerrado sensu stricto (ANC): Located at Palmeiras I Farm, altitude of $813 \mathrm{~m}$ and coordinates $12^{\circ} 1^{\prime} 386^{\prime \prime} \mathrm{S}$ and $46^{\circ} 9^{\prime} 180^{\prime \prime} \mathrm{W}$, under native Cerrado vegetation, without history of any exploitation or human interference.

In each area, a 1 ha $(100 \times 100 \mathrm{~m})$ plot was randomly chosen, where five soil pits were opened with dimensions of approximately $1.5 \mathrm{~m}$ length, $1 \mathrm{~m}$ width and $0.6 \mathrm{~m}$ depth. In each of the pits, of the different areas, undisturbed samples were collected using a volumetric ring at depths of $0-5,5-10$, $10-15,15-20,20-30,30-40$ and $40-60 \mathrm{~cm}$, to determine soil bulk density. At the same depths, disturbed samples were collected with an auger. The samples were taken to the Physics and Chemistry Laboratory of Universidade do Estado da Bahia, where they were air dried, pounded to break up clods and passed through 2-mm-mesh sieves to obtain air-dried fine earth (ADFE).

The organic $\mathrm{C}$ content was quantified by wet oxidation of organic matter with potassium dichromate in sulfuric medium, and total $\mathrm{N}$ content was determined by Kjeldahl by steam distillation, both following the method of EMBRAPA (1997).

$\mathrm{C}$ and $\mathrm{N}$ stocks were obtained by correcting the soil mass using the layer and equivalent soil mass through the reference soil mass (Ellert et al., 2001). For the calculation of the equivalent mass, the relative soil mass was considered in the different forms of use by Eq. 1.

$$
\text { Msoil }=\text { BD T A }
$$

where:

Msoil - soil mass, $\mathrm{Mg} \mathrm{ha}^{-1}$;

$\mathrm{BD}$ - soil bulk density, $\mathrm{Mg} \mathrm{m}^{-3}$;

$\mathrm{T}$ - thickness, $\mathrm{m}$; and,

A - area, $10,000 \mathrm{~m}^{2}$.

After defining the soil mass, the area under native Cerrado (ANC) was considered as a reference area. Then, the soil layers to be added or subtracted in order to equalize the masses of soil of the treatments were calculated. Eq. 2 was used to calculate the layers to be added or subtracted. 


$$
\operatorname{Tad} / \mathrm{sub}=\frac{(\text { Mref }- \text { Marea }) \text { Fha }}{\text { BD }}
$$

where:

$\mathrm{Tad} /$ sub - thickness of the soil layer to be added (+) or subtracted (-), expressed in $\mathrm{m}$;

Mref - equivalent soil mass of the reference area, ANC, $\mathrm{Mg} \mathrm{ha}^{-1}$;

Marea - equivalent soil mass of the area, $\mathrm{Mg} \mathrm{ha}^{-1}$;

Fha - factor of conversion from ha to $\mathrm{m}^{2}, 0.0001 \mathrm{ha} \mathrm{m}^{-2}$; and, $\mathrm{BD}$ - soil bulk density, $\mathrm{Mg} \mathrm{m}^{-3}$.

$\mathrm{C}$ and $\mathrm{N}$ stocks in equivalent mass were obtained by Eq. 3:

$$
\text { Stock }=\mathrm{cc} \mathrm{BD}(\mathrm{T} \pm \mathrm{Tad} / \mathrm{sub}) \text { A Fkg }
$$

where:

Stock - stock of $\mathrm{C}$ or $\mathrm{N}$ per unit of area in equivalent layer, $\mathrm{Mg} \mathrm{ha}^{-1}$;

cc - content of $\mathrm{C}$ or $\mathrm{N}, \mathrm{g} \mathrm{kg}^{-1}$;

$\mathrm{BD}$ - soil bulk density, $\mathrm{Mg} \mathrm{m}^{-3}$;

$\mathrm{T}$ - thickness of the studied soil layer, $\mathrm{m}$;

$\mathrm{Tad} / \mathrm{sub}$ - thickness of the soil layer to be added (+) or subtracted (-), m;

A - area, considering 1 ha, i.e. $10,000 \mathrm{~m}^{2}$; and,

Fkg - factor of conversion from $\mathrm{kg}$ to $\mathrm{Mg}, 0.001 \mathrm{Mg} \mathrm{ha}^{-1}$.

The obtained data were analyzed considering a completely randomized design, with five replicates. The results were subjected to analysis of variance and the means were compared by Tukey test at $\mathrm{p} \leq 0.05$. Principal component analysis was used as a multivariate technique, due to the large number of variables available, in order to identify the similarity between the areas under different forms of land use. The criteria used to choose the number of components were eigenvalues above 1 and accumulated variance above $70 \%$. The analysis was carried out using SAS (1999).

\section{Results AND Discussion}

In the studied areas, it was found that no-tillage cultivation resulted in a significant difference in the total $\mathrm{C}$ content at the surface depth of up to $5 \mathrm{~cm}$, compared to conventional cultivation, pasture and eucalyptus (Figure 1A). This occurred because of the absence of cultivation operations in no-tillage, resulting in a lower rate of decomposition/mineralization and, consequently, maintenance and accumulation of soil organic matter (SOM). In addition, this form of use guarantees the continuous flow of substrate and energy to soil organisms (Roscoe et al., 2005), from crop rotation and soil cover.

It was observed that no-tillage did not significantly increase the $\mathrm{C}$ content at depths below $10 \mathrm{~cm}$ compared to areas under eucalyptus cultivation and native Cerrado vegetation, and the low $\mathrm{C}$ content is associated with the short time of adoption of no-tillage, which was only 4 years, since $\mathrm{C}$ accumulation occurs slowly, taking more than 10 years to become significant (Carvalho et al., 2009; Guareschi et al., 2014). Dieckow et al. (2009) also found reduction in C contents at the studied depths

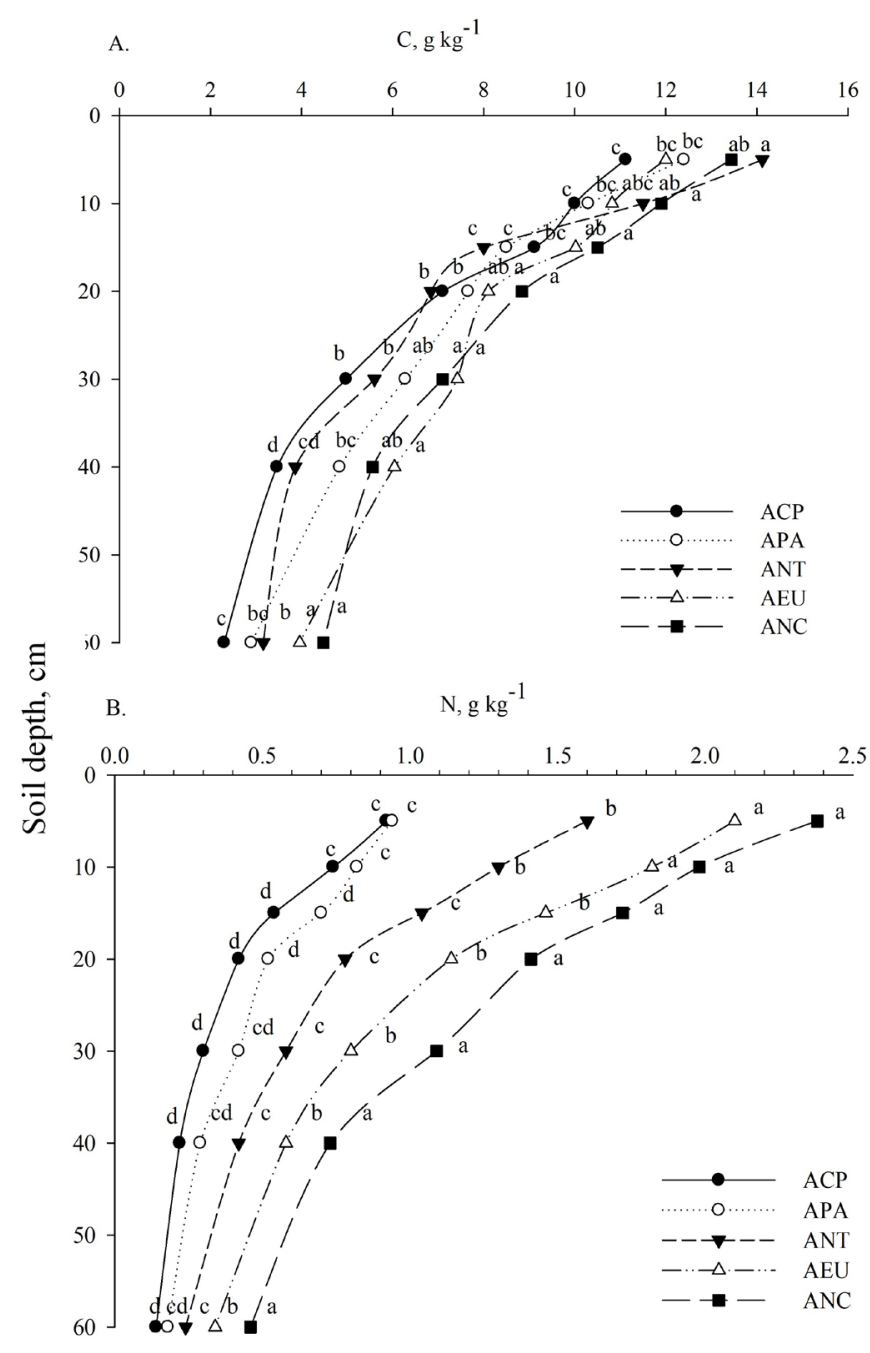

Means followed by same letters in the same row do not differ by Tukey test at $\mathrm{p} \leq 0.05$

Figure 1. Total organic carbon (A) and total nitrogen (B) contents in areas under conventional planting $(\mathrm{ACP})$, pasture planting (APA), no-tillage (ANT) eucalyptus plantation (AEU) and native Cerrado vegetation (ANC)

for no-tillage in comparison to areas under Cerrado. Regardless of the depth studied, the area under conventional planting had the lowest $\mathrm{C}$ content, corresponding to $10.4,19.08$ and $21.8 \%$ of the values found in the areas under pasture, eucalyptus and native Cerrado vegetation, respectively (Figure 1A). Studies conducted by Tesfaye et al. (2016), in central African soils, demonstrate a loss of up to $26.4 \%$ of $\mathrm{C}$ when an area under native vegetation is replaced with areas under plantations.

Eucalyptus cultivation increased the $\mathrm{C}$ content at the depth below $10 \mathrm{~cm}$ compared to the other forms of land use, but did not differ from the area under native Cerrado vegetation. This result is associated with the contribution of plant residues over time due to eucalyptus cultivation, since the crop had been planted eight years ago.

Regarding the results of total N, the area under no-tillage had lower values compared to the those under eucalyptus and native Cerrado vegetation and higher values compared to the areas under pasture and conventional planting up to $20 \mathrm{~cm}$ (Figure 1B).

It is also observed that there were significant differences between the area under eucalyptus cultivation and the other forms of land use such as pasture, no-tillage and conventional at 
all depths, and that the cultivation of pasture and conventional planting had the lowest values of $\mathrm{N}$, compared to the other forms of land use (Figure 1B).

The lowest $\mathrm{C} / \mathrm{N}$ ratio was found in the area under eucalyptus cultivation (approximately 6) at the depth of up to $10 \mathrm{~cm}$, in comparison to no-tillage, pasture and conventional planting, thus contributing to an increase in $\mathrm{N}$ content.

In relation to the $\mathrm{C}$ stock, it was verified that no-tillage increased the stocks in comparison to the area under conventional planting up to $5 \mathrm{~cm}$ depth (Figure 2A), with values of 8.7 and $6.5 \mathrm{Mg} \mathrm{ha}^{-1}$, respectively. The highest values of $\mathrm{C}$ stock in the soil surface are consistent with the greater deposition of residues on the soil surface (Dortzbach et al., 2015) from crop rotation and due to the absent or lower soil turning, which leads to greater storage of C. In addition, for the same authors, C stock tends to increase in areas under the use of conservation practices due to a greater physical protection of organic compounds against microbial decomposition and, consequently, a greater occlusion of $\mathrm{C}$ in soil aggregates, besides the chemical protection of organic compounds through the interaction of these compounds with minerals and cations of the soil.

The area under conventional planting showed the lowest stock of $\mathrm{C}$ in the surface layer $(0-5 \mathrm{~cm})$ with reductions of

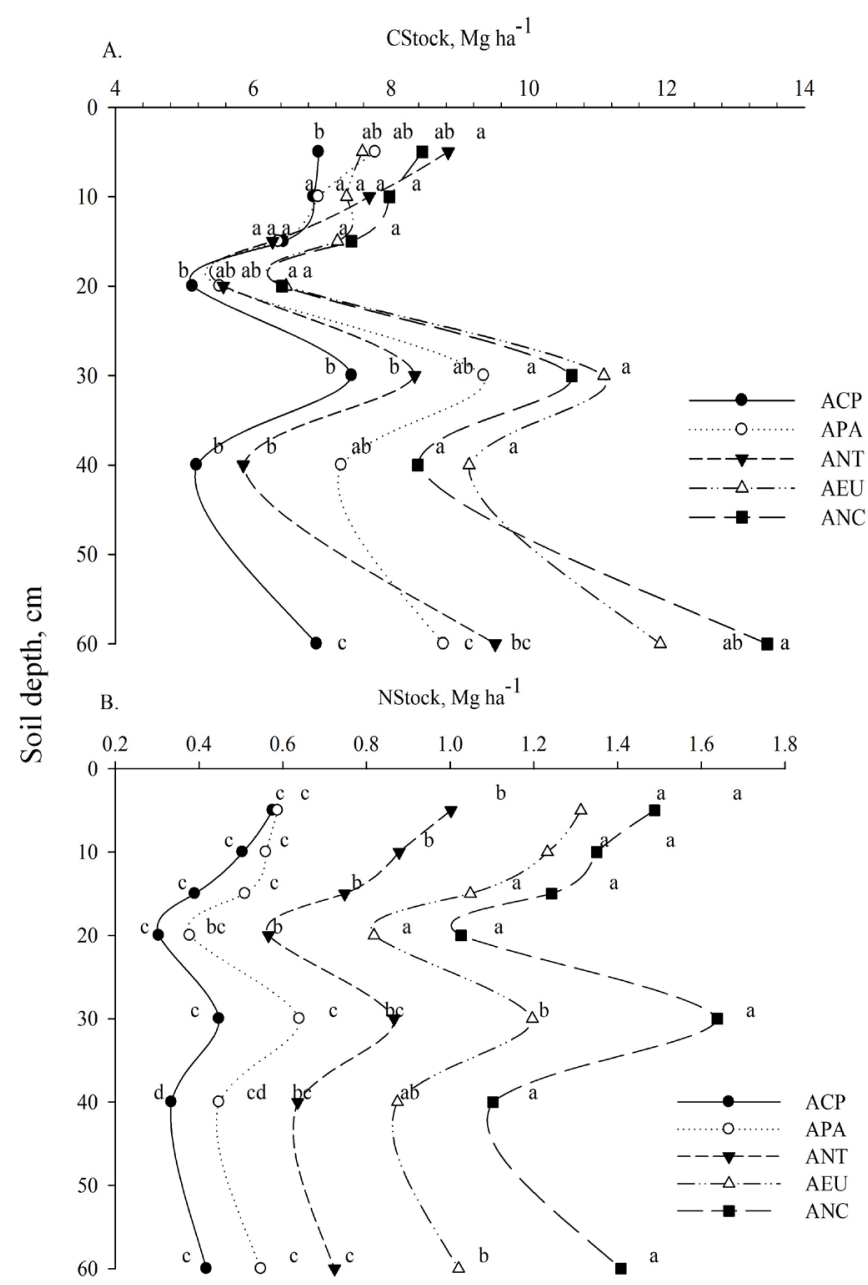

Means followed by equal letters in the same row do not differ by Tukey test at $\mathrm{p} \leq 0.05$ Figure 2. Stocks of total organic carbon - CStock (A) and total nitrogen - NStock (B), in areas under conventional planting (ACP), pasture planting (APA), no-tillage (ANT), eucalyptus plantation (AEU) and under native Cerrado vegetation (ANC) up to $18 \%$ and below $20 \mathrm{~cm}(20-30,30-40$ and $40-60 \mathrm{~cm})$ with a decrease of up to $43 \%$, when compared to areas under eucalyptus and native Cerrado vegetation. The use of burning and harrowing practices probably contributes to the occurrence of this effect.

Pasture cultivation did not increase $\mathrm{C}$ stock in the layer up to $40 \mathrm{~cm}$ in comparison to other forms of land use, with lower values below this depth compared to eucalyptus cultivation and native Cerrado vegetation. These results can be attributed to the root system of the pastures because, in general, $46 \%$ of their roots are in the soil surface layer of up to $10 \mathrm{~cm}$ (Rangel \& Silva, 2010). The increase or reduction of C stocks in areas under pasture may also result from the management applied to forage crops, which can be observed in this area of study, where low vigor plants developed, and maintenance.

In areas cultivated with eucalyptus, the $\mathrm{C}$ stock was higher in comparison to the areas under no-tillage and conventional planting at depths below $20 \mathrm{~cm}$. Most (about 53\%) of this C stock is concentrated at depths below $20 \mathrm{~cm}$.

In general, there were significant changes in soil $\mathrm{N}$ stocks regardless of the studied depths (Figure 2B). Areas under native Cerrado vegetation and eucalyptus cultivation did not differ from each other up to the depth of $20 \mathrm{~cm}$ and had higher values of $\mathrm{N}$ stock in comparison to other forms of land use. The litter formed in areas under eucalyptus cultivation over the years, associated with the absence of soil turning, characteristics also of the areas under native Cerrado vegetation, is important in the maintenance and formation of soil organic matter. On the other hand, the intense practices of soil tillage, found mainly in the areas under conventional planting, accelerate the processes of $\mathrm{N}$ volatilization and leaching, thus reducing its stocks.

The principal components (PC) were able to discriminate the forms of land use with their respective depths, and the most important ones were those with eigenvalues greater than 1 (Vicini, 2005). Based on this criterion, the principal components 1, 2 and 3 explain 40.5, 26.6 and 13.8\% of the total variance, respectively, accumulating $80.9 \%$ of the total variance of the data.

The eigenvectors of the variables analyzed in the forms of land use for each principal component can be observed in Table 1 .

The first principal component (PC1) showed that, of the set of soil variables, the greatest influence was caused by $\mathrm{C}$ and

Table 1. Eigenvectors of the variables analyzed in an Oxisol of areas under different forms of land use with the principal components (PC1, PC2 and PC3)

\begin{tabular}{lccc}
\hline Variables & PC1 & PC2 & PC3 \\
C & $-0.39^{*}$ & $0.29^{*}$ & -0.02 \\
N & $-0.46^{*}$ & 0.04 & -0.12 \\
LOM & $-0.28^{*}$ & $0.30^{*}$ & 0.12 \\
BD & $0.43^{*}$ & 0.20 & 0.09 \\
TP & 0.09 & 0.02 & $-0.43^{*}$ \\
Sand & -0.16 & $0.50^{*}$ & 0.21 \\
Silt & 0.13 & -0.11 & $-0.60^{*}$ \\
Clay & 0.02 & $-0.41^{*}$ & $0.46^{*}$ \\
CStock & -0.08 & $-0.42^{*}$ & 0.17 \\
NStock & $-0.36^{*}$ & $-0.34^{*}$ & -0.02 \\
\hline
\end{tabular}

"Eigenvectors of highest representativeness for the principal components (PC1, PC2, PC3); C - Carbon; N - Nitrogen; LOM - Light organic matter; BD - BD density; TP - Total porosity; CStock - Carbon stock; NStock - Nitrogen stock 
$\mathrm{N}$ contents, light organic matter, bulk density and $\mathrm{N}$ stock, which had the highest eigenvectors, thus demonstrating that the forms of use with their respective managements altered the various soil attributes. It is observed that the light organic matter was inversely correlated only with bulk density, which did not occur for $\mathrm{C}$ and $\mathrm{N}$ contents and $\mathrm{N}$ stock, that is, with the maintenance of soil organic matter there are increments in these variables, except for soil bulk density. Similar results regarding the effect of soil organic matter on soil bulk density can be observed in several studies (Amaro Filho et al., 2008; Melo et al., 2008; Mota et al., 2015).

The second principal component (PC2) showed, through the eigenvectors, the variables $\mathrm{C}$ content, light organic matter, sand, clay, and $\mathrm{C}$ and $\mathrm{N}$ stocks. It was observed that the increase in clay caused increments in $\mathrm{C}$ and $\mathrm{N}$ stocks. It is important to highlight that the behavior between both variables is related to the greater physical protection (through the formation of barriers, reducing the direct contact of microorganisms with soil organic matter, and reduction of oxygen flow in the environment) and chemical protection ( $\mathrm{Ca}, \mathrm{Mg}$ and others) caused by clay, which does not occur in the sand fraction.

The third principal component (PC3) demonstrated a contrast of total porosity with the clay fraction and silt fraction. The inverse correlation between silt and clay fractions can be understood through pedogenesis, as physical and chemical weathering acts on larger fractions, in the case of silt, originating the smaller fractions, clay (Mota et al., 2015). Total porosity may be affected by other processes, e.g. soil compaction.

The distribution of the variables analyzed for the forms of land use and their depths is shown in Figure 3, represented by vectors in five groups.

Group I comprised the areas under native Cerrado vegetation, eucalyptus plantation and under no-tillage, the first two with depths of up to $20 \mathrm{~cm}$ and the last with a surface depth of up to $5 \mathrm{~cm}$. These areas with their respective depths were highlighted because of the variables total porosity, $\mathrm{N}$ content and $\mathrm{N}$ stock. This pattern indicated that no-tillage and eucalyptus cultivation, being replaced by the area under

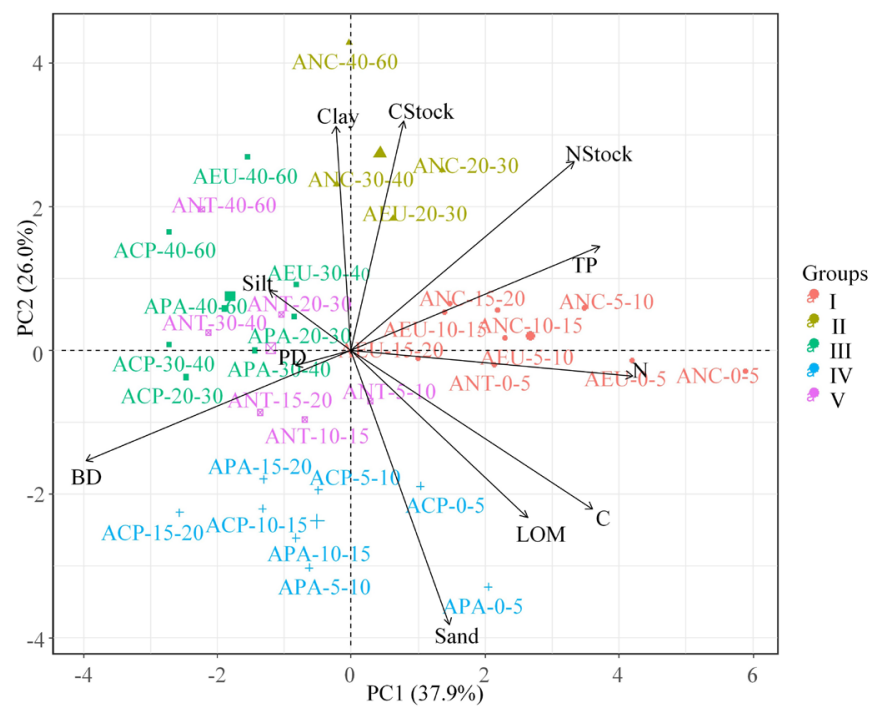

LOM - Light organic matter; BD - Bulk density; PD - Particle density; C - Carbon content N - Nitrogen content; CStock - Carbon stock; NStock - Nitrogen stock; Sand; Silt; Clay Figure 3. Dispersion of the analyzed variables and formation of groups for different forms of land use and depths native Cerrado vegetation, favor an increase in these variables, corroborating the data of Figures 1 and 2. The area under eucalyptus has been cultivated for eight years, where little anthropic interference contributed to the recovery of soil properties; in the area under no-tillage, it is demonstrated that the displacement of biomass to greater depths depends on the period of implementation, and four years are not sufficient to recover the soil properties in subsurface.

Close to group I, there are the areas under native Cerrado vegetation (depth from 20 to $60 \mathrm{~cm}$ ) and eucalyptus cultivation (depths from 20 to $30 \mathrm{~cm}$ ), forming group II. This proximity is due to the variables $\mathrm{C}$ stock and clay, which may be related to the greater chemical and physical protection of SOM.

In group III, it was possible to observe the forms of land use with the deepest layers, below $20 \mathrm{~cm}$. In this case, the areas under eucalyptus (depths from 30 to $60 \mathrm{~cm}$ ), conventional planting and pasture (depths from 20 to $60 \mathrm{~cm}$ ) were grouped.

Group IV was formed by the areas under pasture and conventional planting with depths from 0 to $20 \mathrm{~cm}$, and the most superficial depths $(0-5 \mathrm{~cm})$ stood out from the others due to the sand variable.

For group $\mathrm{V}$, soil bulk density influenced mainly the area under no-tillage at depths of $10-15$ and $15-20 \mathrm{~cm}$, while at a depth of $5-10 \mathrm{~cm}$, the sand content stands out.

\section{Conclusions}

1. The area under no-tillage increases $C$ content and $C$ stock only at the surface depth of up to $10 \mathrm{~cm}$ with values higher than $1 \mathrm{Mg} \mathrm{ha}^{-1}$, while the cultivation of eucalyptus favors an increase of at least $7 \mathrm{Mg} \mathrm{ha}^{-1}$ at depths from 20 to $60 \mathrm{~cm}$, compared to the other forms of land use.

2. Eucalyptus cultivation contributes to increasing $\mathrm{N}$ content and $\mathrm{N}$ stock at all depths evaluated, followed by notillage up to $15 \mathrm{~cm}$ depth.

3. Based on the principal components, it was found that the variables light organic matter (LOM), contents and stocks of carbon $(\mathrm{C})$ and nitrogen $(\mathrm{N})$, bulk density $(\mathrm{BD})$ and particle density (PD) influence the distinction of the different forms of land use.

\section{ACKnowledgments}

Thanks to Conselho Nacional de Desenvolvimento Científico e Tecnológico - (CNPq) for the financial support given to the Research Project 466137/2015-4 - Call MCTI/ CNPq/ANA No 23/2015 - Pesquisa em Mudança do Clima.

\section{Literature Cited}

Amaro Filho, J.; Assis Júnior, R. N.; Mota, J. C. A. Física do solo: Conceitos e aplicações. Fortaleza: Imprensa Universitária, 2008. 290p.

Carvalho, J. L. N.; Cerri, C. E. P.; Feigl, B. J.; Picollo, M. C.; Godinho, V. P.; Cerri, C. C. Carbon sequestration in agricultural soils in the Cerrado region of the Brazilian Amazon. Soil and Tillage Research, v.103, p.342-349, 2009. https://doi.org/10.1016/j. still.2008.10.022 
Costa, N. R.; Andreotti, M.; Lopes, K. S. M.; Yokobatake, K. L.; Ferreira, J. P.; Pariz, C. M.; Bonini, C. dos S. B.; Longhini, V. Z. Atributos do solo e acúmulo de carbono na integração lavoura-pecuária em sistema plantio direto. Revista Brasileira de Ciência do Solo, v.39, p.863-852, 2015. https://doi.org/10.1590/01000683rbcs20140269

Dieckow, J.; Bayer, C.; Conceição, P. C.; Zanatta, J. A.; Martin-Neto, L.; Milori, D. B. N.; Salton, J. C.; Macedo, M. M.; Mielniczuk, J.; Hernani, L. C. Land use, tillage, texture and organic matter stock and composition in tropical and subtropical Brazilian soils. European Journal of Soil Science, v.60, p.240-249, 2009. https:// doi.org/10.1111/j.1365-2389.2008.01101.x

Dortzbach, D.; Pereira, M. G.; Blainski, E.; González, A. P. Estoque de $\mathrm{C}$ e abundância natural de ${ }^{13} \mathrm{C}$ em razão da conversão de áreas de floresta e pastagem em bioma mata atlântica. Revista Brasileira de Ciência do Solo, v.39, p.1643-1660, 2015. https:// doi.org/10.1590/01000683rbcs20140531

Ellert, B. H.; Janzer, H. H.; Mcconkey, B. G. Measuring and comparing soil carbon storage. In: Lal, R.; Kimbler, J. M.; Follet, R. F.; Stewart, B. A. Assessment methods for soil carbon. Florida: Boca Raton, 2001. Cap.10, p.131-146.

EMBRAPA - Empresa Brasileira de Pesquisa Agropecuária. Manual de métodos e análise de solo. 2.ed. Rio de Janeiro: Embrapa Solos, 1997. 212p.

Frazão, L. A.; Santana, I. K. da S.; Campos, D. V. B. de; Feigl, B. J.; Cerri, C. C. Estoque de carbono e nitrogênio e fração leve da matéria orgânica em Neossolo Quartzarênico sob uso agrícola. Pesquisa Agropecuária Brasileira, v.10, p.1198-1204, 2010. https:// doi.org/10.1590/S0100-204X2010001000020

Guareschi, R. F.; Pereira, M. G.; Perin, A. Estoque de carbono em latossolo vermelho distroférrico sob diferentes sistemas de manejo. Revista Brasileira de Ciências Agrárias, v.7, p.597-602, 2012. https://doi.org/10.5039/agraria.v7i4a1767

Guareschi, R. F.; Pereira, M. G.; Perin, A. Carbono, nitrogênio e abundância natural de $\delta^{13} \mathrm{C}$ e $\delta^{15} \mathrm{~N}$ em um cronossequência de agricultura sob plantio direto no cerrado goiano. Revista Brasileira de Ciência do Solo, v.38, p.1135-1142, 2014. https:// doi.org/10.1590/S0100-06832014000400009
Matias, M. C. B. da S.; Salviano, A. A. C.; Leite, L. F. de C.; Araújo, A. S. F. de. Biomassa microbiana e estoque de $\mathrm{C}$ e $\mathrm{N}$ do solo em diferentes sistemas de manejo, no cerrado do estado do Piauí. Acta Scientiarum. Agronomy, v.31, p.517-521, 2009. https://doi. org/10.4025/actasciagron.v31i3.687

Melo, R. O.; Pacheco, E. P.; Menezes, J. de C.; Cantalice, J. R. B. Susceptibilidade à compactação e correlação entre as propriedades físicas de um Neossolo sob vegetação de Caatinga. Revista Caatinga, v.21, p.12-17, 2008.

Mota, J. C. A.; Alencar, T. L. de; Assis Júnior, R. N. Alterações físicas de um cambissolo cultivado com bananeira irrigada na Chapada do Apodi, Ceará. Revista Brasileira de Ciência do Solo, v.39, p.10151024, 2015. https://doi.org/10.1590/01000683rbcs20140018

Pereira, M. G.; Loss, A.; Beutler, J.; Torres, J. L. R. Carbono, matéria orgânica leve e fósforo remanescente em diferentes sistemas de manejo do solo. Pesquisa Agropecuária Brasileira, v.4, p.508-514, 2010. https://doi.org/10.1590/S0100-204X2010000500010

Rangel, O. J. P.; Silva, C. A. Estoque de carbono e nitrogênio e frações orgânicas de Latossolo submetido a diferentes sistemas de uso e manejo. Revista Brasileira de Ciência do Solo, v.10, p.1198-1204, 2010.

Roscoe, R.; Buurman, P.; Velthorst, E. J.; Pereira, J. A. A. Effects of fire on soil organic matter in a "cerrado sensu-stricto" from Southeast Brazil as revealed by in $\delta^{13} \mathrm{C}$. Geoderma, v.95, p.141-160, 2005. https://doi.org/10.1016/S0016-7061(99)00089-0

SAS - Statistical analysis system. SAS System for windows version 8.0 Cary: Statistical Analysis System, 1999. CD-Rom

Tchienkoua, M.; Zeach, W. Organic carbon and plant nutrient dynamics under three land uses in the highlands of West Camerron. Agriculture, Ecosystems \& Environment, v.104, p.673679, 2004. https://doi.org/10.1016/j.agee.2003.10.007

Tesfaye, M. A.; Bravo, F.; Ruiz-Peinado, R.; Pando, V.; Bravo-Oviedo, A. Impact of changes in land use, species and elevation on soil organic carbon and total nitrogen in Ethiopian Central Highlands. Geoderma, v.261, p.70-79, 2016. https://doi.org/10.1016/j. geoderma.2015.06.022

Vicini, L. Análise multivariada da teoria à prática. Santa Maria: Universidade Federal de Santa Maria, 2005. 215p. 